\title{
Éditorial
}

\section{Imagerie motrice : principes, concepts et méthodes}

\author{
Aymeric Guillot, Christian Collet
}

L'objectif de ce numéro spécial est de faire un état des recherches actuelles sur l'imagerie motrice définie comme la représentation mentale d'un mouvement ou d'une séquence motrice, sans qu'elle soit accompagnée ou suivie par son exécution. Nous avons sollicité des chercheurs reconnus dans ce domaine afin de questionner les approches conceptuelles et diversifier les applications pratiques. Tous ont accepté de collaborer et nous les en remercions vivement. Leurs contributions permettent d'actualiser les connaissances, d'en étendre la richesse et la portée théorique.

Longtemps, la recherche sur l'imagerie motrice est restée du domaine de la psychologie. Dans le chapitre 18 , intitulé «Imagination » de son célèbre « Principles of Psychology », William James (1890 Vol. 2, pages 30 à 55) pose la question de savoir si l'imagerie motrice ne serait pas une forme de réactivation des impressions provenant des parties corporelles qui ont été sollicitées par d'anciens mouvements. L'image ainsi générée devrait reproduire leurs caractéristiques intrinsèques. L'idée générale d'un support biologique aux processus mentaux comme la représentation mentale n'a été rapportée que tardivement au fonctionnement cérébral. L'esprit est longtemps resté séparé des fonctions corporelles. Pourtant Munk (1881) avait pensé que les impressions de la sensibilité générale devaient être associées pour former des images conservées en mémoire. Une contribution méconnue à la construction des représentations est celle de Freud qui leur donna même un support structural. Son texte, écrit en 1895, mais publié en 1950 seulement, attribue l'origine de la construction d'une image interne aux neurones psi, ainsi dénommés parce que supposés sans connexion ni avec les récepteurs, ni avec les effecteurs Ils seraient reliés aux neurones moteurs et pourraient déclencher l'action destinée à atteindre un but née sous la forme d'une image. On arrive à une représentation préalable à l'action où on se contente de l'imaginer, avec la possibilité de lui associer des conséquences sensorielles. Cette capacité à créer des états fonctionnels correspondant à différents aspects potentiels de la réalité nécessite que des représentations s'intercalent entre la perception et l'action. Des progrès évidents ont été réalisés par les neurophysiologistes du XIX ${ }^{\mathrm{e}}$ et du début du $\mathrm{XX}^{\mathrm{e}}$ siècle. C'est Kenneth Craik (1943) qui a proposé le premier le concept de modèle interne pour décrire les propriétés d'une représentation. Selon Jeannerod (1996, page 208), la notion de centres d'images était répandue à la fin du XIX ${ }^{\mathrm{e}}$ siècle et l'évocation d'images, en particulier de mouvements, pouvait expliquer de nombreuses fonctions psychiques, comme le démontrera ultérieurement la psychologie cognitive avec le concept de représentation interne. Ce n'est qu'à la fin du $\mathrm{XX}^{\mathrm{e}}$ siècle que les propriétés de l'imagerie motrice ont été associées à celles de l'exécution réelle, pour en renforcer l'efficacité. À partir de la première étude marquante attestant l'effet facilitateur de l'imagerie motrice sur l'apprentissage moteur (Feltz et Landers, 1983), ses domaines d'applications se sont élargis pour entrer dans le champ du recouvrement des fonctions motrices. La question initiale était de savoir comment les pathologies motrices pouvaient affecter l'imagerie motrice (e.g. . Decety et Boisson, 1990). Cette interrogation première s'est renversée pour identifier ses potentielles contributions à la rééducation motrice (Decety, 1993). L'apport des neurosciences et l'orientation clinique des travaux menés ces dernières années ont finalement permis d'étendre et de diversifier ce domaine thématique. Il se situe ainsi naturellement aujourd'hui à l'interface de nombreux courants théoriques.

La première partie de ce numéro thématique s'intéresse à l'étude théorique des fondements neurophysiologiques de l'imagerie motrice.

- Christian Collet, Franck Di Rienzo, Nady Hoyek et Aymeric Guillot (Université Claude Bernard Lyon 1; Institut Universitaire de France, Paris, France) abordent la question de l'évaluation des capacités d'imagerie et de la qualité du travail mental. Ils synthétisent notamment les corrélats neurophysiologiques de l'imagerie motrice, qu'ils soient centraux ou périphériques.

- Florent Lebon, Nicolas Gueugneau et Charalambos Papaxanthis (Université de Bourgogne, Dijon, France) décrivent les apports de la stimulation magnétique transcrânienne dans l'étude de l'imagerie 
motrice. Ils précisent notamment en quoi l'imagerie motrice facilite l'excitabilité corticomotrice et réduit l'inhibition intracorticale.

Elke Heremans, Sarah Vercruysse Joke Spildooren, Peter Feys, Werner F. Helsen et Alice Nieuwboer (Katholieke Universiteit Leuven et Universiteit Hasselt, Belgique) décrivent les batteries de tests permettant d'évaluer les capacités d'imagerie chez les patients et plus spécifiquement l'enregistrement des mouvements oculaires. L'application chez les patients atteints de la maladie de Parkinson et de la sclérose en plaque illustre leurs propos.

La seconde partie comprend 4 articles utilisant l'imagerie pour favoriser et consolider les apprentissages moteurs.

- Ursula Debarnot et Aymeric Guillot (Université Claude Bernard Lyon 1; Centre de Psychiatrie et Neurosciences $\&$ Institut Universitaire de France, Paris, France) proposent une synthèse dans laquelle ils montrent comment le sommeil favorise la consolidation de la trace mnésique après un entraînement mental. Leurs récentes données permettent d'enrichir les modalités de pratique et la réflexion autour de la planification du travail mental.

Florent Lebon, Nicolas Gueugneau et Charalambos Papaxanthis (Université de Bourgogne, Dijon, France) questionnent l'imagerie motrice à travers les modèles internes. La prédiction des caractéristiques comportementales du mouvement et leur ajustement grâce aux interactions entre corps et environnement permettraient de mieux comprendre l'efficacité de l'imagerie motrice.

- Lucette Toussaint et Yannick Blandin (Université de Poitiers, France) se sont intéressés aux effets de différentes modalités d'imagerie sur le sens de la position. Leurs résultats montrent l'importance des capacités et/ou de la pratique préalable de l'imagerie kinesthésique. Les auteurs soulignent l'intérêt d'évaluer les capacités d'imagerie dans chacune des modalités sensorielles afin de rentabiliser les bénéfices de la pratique mentale.

- Jennifer Cummings et Sarah Williams (Université de Birmingham, Angleterre) présentent une réflexion synthétique sur la complémentarité des composantes motivationnelles et cognitives de l'imagerie motrice. Elles proposent une actualisation du « Applied Model of Imagery Use» de Martin et al. (1999).

La troisième partie regroupe 5 contributions offrant des orientations cliniques pour mieux comprendre le rôle potentiel de l'imagerie motrice dans le recouvrement des fonctions motrices.

- Arnaud Saimpont, Francine Malouin et Philip L. Jackson (Université de Laval, Centre interdisciplinaire de recherche en réadaptation et intégration sociale Québec, Canada) interrogent l'efficacité de l'imagerie motrice dans le traitement de trois formes de douleurs neuropathiques : les douleurs fantômes, le syndrome douloureux régional complexe et les douleurs consécutives à une lésion de la moelle épinière. S'ils soulignent l'apport thérapeutique de la pratique mentale dans ce domaine, ils attirent également l'attention sur le fait que tous les patients n'y répondent pas positivement et décrivent les processus neurophysiologiques des effets antalgiques potentiels de l'imagerie.

- Nadja Schott, Marie-Ottilie Frenkel, Heide Korbus et Karen L. Francis (Université de Stuttgart et d'Heidelberg, Allemagne; Université de San Francicsco, USA) présentent les fondements théoriques de l'utilisation de l'imagerie dans le domaine de la rééducation orthopédique. Elles proposent une nouvelle structuration du travail mental dans la période de rééducation sur la base de la taxonomie de Gentile (2000) et illustrent leur propos par une étude de cas chez un patient victime d'une fracture du radius.

- Estelle Raffin et Karen Reilly (Université Jean Monnet, Saint-Etienne, France; Danish Research Center on Magnetic Resonance, Copenhague, Danemark; Centre de Neurosciences Cognitives et Centre de Recherche des Neurosciences de Lyon, France) synthétisent les données relative à la perception du membre fantôme chez les patients amputés Elles s'interrogent sur les réseaux cérébraux qui pourraient contrôler la perception de mouvement du segment amputé et sur leur rapport avec le concept d'imagerie motrice.

Audrey Maillet, Valérie Fraix, Stéphane Thobois, Philippe Derost, Bastiaan Bloem, Pierre Pollak et Bettina Debû (Université de Grenoble, Institut des Neurosciences de Grenoble, Centre hospitalier Universitaire de Grenoble, France; Hospices Civils de Lyon et Institut des Sciences Cognitives, France; Hôpital Gabriel Montpied, Clermont-Ferrand, France; Radboud University Nijmegen Medical Center, Nijmegen, Pays-Bas ; Hôpitaux Universitaires de Genève, Suisse) rapportent une expérimentation dont le but était d'évaluer les capacités d'imagerie chez des patients atteints de la maladie de Parkinson et l'effet de la prise de Levodopa sur la représentation et l'exécution d'une tâche locomotrice. Les résultats montrent des capacités d'imagerie préservées, même à un stade avancé de la maladie. L'imagerie pourrait ainsi constituer une technique prometteuse pour réduire les troubles locomoteurs chez ces patients.

- Francine Malouin, Arnaud Saimpont, Philip L. Jackson et Carol L. Richards (Université de Laval, Centre interdisciplinaire de recherche en réadaptation et intégration sociale Québec, Canada) proposent une revue de littérature centrée sur les bénéfices de l'entraînement par imagerie motrice lors de la récupération des fonctions locomotrices après une atteinte neurologique. Les auteurs décrivent également comment les capacités d'imagerie des patients peuvent être influencées par les atteintes neurologiques et le vieillissement normal.

L'ensemble de ces contributions, tant les travaux expérimentaux que les revues de question, nourrissent le champ des recherches actuelles sur le thème « Pratique mentale et récupération fonctionnelle des capacités motrices ». Que l'atteinte soit centrale ou périphérique, les bénéfices apportés par la pratique de l'imagerie motrice 
démontrent que son intégration dans les programmes de rééducation est pertinente et prometteuse. Au final, ce numéro thématique regroupe 12 contributions de chercheurs reconnus au niveau international. Il délivre un aperçu objectif de l'état actuel des recherches dans le domaine de l'imagerie motrice et de ses effets supposés sur la motricité réelle.

\section{Bibliographie}

Craik, K.J.W. (1943). The nature of explanation Cambridge, Cambridge University Press.

Decety, J., \& Boisson, D. (1990). Effect of brain and spinal cord injuries on motor imagery. European Archives of Psychiatry and Clinical Science, 240, 39-43.
Decety, J. (1993). Should motor imagery be used in physiotherapy? Recent advances in cognitive neurosciences. Physiotherapy Theory and Practice, 9, 193-203.

Feltz, D.L., \& Landers, D.M. (1983). The effects of mental practice on motor skill learning and performance: a metaanalysis. Journal of Sport Psychology, 5, 25-57.

Freud, S. (1950 [1895]). Project for a scientific psychology. Standard Edition, 1, 281-387.

James, W. (1890). Principles of psychology. Chapitre 18: Imagination. Dover Publications.

Jeannerod, M. (1996). About mental physiology: history of the relationships between biology and psychology. Odile Jacob, Paris.

Munk, H. (1881). Uber die Funktionen der Grosshirnrinde (sur les fonctions du cortex cérébral). Hirschwald, Berlin (1890). 


\title{
Editorial
}

\section{Motor imagery: principles, concepts and methods}

\author{
Aymeric Guillot, Christian Collet
}

The aim of this special issue is to provide an overview of research about motor imagery, the mental representation of an action without any overt body movement. Contributions from eminent imagery researchers were gathered to question different theoretical approaches of the imagery experience as well as various practical applications in the field of motor learning and rehabilitation. All scientists kindly agreed to collaborate in this project and we are very grateful for their fruitful contributions which shed light on important data in this area of research.

For a long time, motor imagery research has been restricted to the area of psychology. In the chapter 18 ("Imagination") of his famous book "Principles of Psychology", William James (1890, Vol. 2, pages 30 to 55) questioned whether motor imagery was a kind of reactivation of our impressions and sensations from body parts which have been involved in previous movements. The visual image should therefore include the intrinsic characteristics of the corresponding movements. The idea of a biological substrate of mental processes has been later linked to the cerebral functions. Practically, the body has been separated from the mind for a long time. For Munk (1881), however, the sensitive area is composed of cerebral centres where the impressions of the overall sensitivity are perceived, and then combined to form images stored in the brain. A little-known contribution to the construction of representations is that of the psychoanalyst Freud who gave them a structural support (it remained unknown because this text written in 1895 was published only in 1950). It was based on the description of neurons psi, so called because these were assumed having no connection with receptors or effectors and were believed responsible for the construction of an internal image of the outcome. The neurons psi were thus supposed as being connected to motor neurons and could trigger action thus achieving the goal emerging from an image. This led to motor representation prior to the action including its expected consequences, although the possibility of not performing the imagining movement was not raised. The ability to simulate different possible situations requires that some "mental representations" are formed between perception and action. Substantial scientific advances have been made by neurophysiologists in the $19^{\text {th }}$ and beginning of the $20^{\text {th }}$ centuries. Kenneth Craik (1943) first suggested the concept of internal model to describe the properties of a representation. With reference to artificial intelligence, he defined an internal model as the ability to simulate both external reality and its own internal functional status, thus predicting the consequences of an action before its execution. According to Jeannerod (1996, page 208) evocating images, and more specifically mentally simulating movements might explain several psychic functions, as shown lately by some cognitive psychologists with the concept of internal representation. The intrinsic properties of mental images have then been associated to those of the physical execution of the same movement at the end of the $20^{\text {th }}$ century, in order to improve the efficacy of actual practice. Since one of the most well-known experimental study demonstrating that motor imagery may contribute to improve motor learning (Feltz and Landers, 1983), clinical imagery interventions have been implemented with the aim to improve motor recovery. The initial question was to determine whether motor impairments altered motor imagery (e.g., Decety and Boisson, 1990), before investigating the imagery-related therapeutic benefits during rehabilitation (Decety, 1993). The contribution of neuroscience research and clinical settings in recent years expanded this research area, which is now quite naturally at the interface between many theoretical approaches.

The first part of this special issue raises theoretical questions by considering the neurophysiological foundations of motor imagery.

- Christian Collet, Franck Di Rienzo, Nady Hoyek and Aymeric Guillot (Université Claude Bernard Lyon 1; Institut Universitaire de France, Paris, France) question the assessment of imagery ability and quality. They provide an overview of the neurophysiological correlates of the imagery experience, based on either central or peripheral nervous system recordings.

- Florent Lebon, Nicolas Gueugneau and Charalambos Papaxanthis (Université de Bourgogne, Dijon, France) explain the modulation of corticospinal excitability during motor imagery in response to 
Transcranial Magnetic Stimulation (TMS) measures They also question why imagery is likely to reduce intracortical inhibition.

Elke Heremans, Sarah Vercruysse Joke Spildooren, Peter Feys, Werner F. Helsen and Alice Nieuwboer (Katholieke Universiteit Leuven and Universiteit Hasselt, Belgium) review the different tests designed to assess imagery ability in patients. They specifically consider the benefits of eye movement recordings. They finally discuss experimental findings in patients with Parkinson's disease and multiple sclerosis.

The second section then turns to the use and benefits of imagery in motor (re)learning.

Ursula Debarnot and Aymeric Guillot (Université Claude Bernard Lyon 1; Centre de Psychiatrie et Neurosciences \& Institut Universitaire de France, Paris, France) first propose an opinion paper outlining why and how sleep contributes to motor consolidation after motor imagery practice These recent results provide fruitful orientations for scheduling and performing imagery appropriately and efficiently.

Florent Lebon, Nicolas Gueugneau and Charalambos Papaxanthis (Université de Bourgogne, Dijon, France) question the imagery processes with regard to the concept of forward model. They postulate that predicting the outcome and the sensory consequences of the movement, and modulating such predictions through the body/environment interaction, may contribute to explain both the structure and the efficacy of the imagery experience.

- Lucette Toussaint and Yannick Blandin (Université de Poitiers, France) investigated the effect of imagery type on the sense of body position. Their data highlight the importance of kinesthetic imagery ability and practice. They further outline that imagery ability should be assessed within each imagery type/modality to make more effective the potential benefits of motor imagery.

- Jennifer Cummings and Sarah Williams (Université de Birmingham, England) review literature on cognitive and motivational imagery use in the sport, exercise, dance, and rehabilitation domains and further outline a revised version of the "Applied Model of Imagery Use" by Martin et al. (1999).

The last part of the special issue is made of 5 contributions offering clinical orientations and applications of imagery use in order to improve motor recovery in different kinds of patients.

- Arnaud Saimpont, Francine Malouin and Philip L. Jackson (Université de Laval, Centre interdisciplinaire de recherche en réadaptation et intégration sociale Québec, Canada) question the efficacy of imagery following three types of neuropathic pain: phantom-limb pain in amputees, complex regional pain syndrome, and pain after spinal cord injury. While they support the therapeutic benefits of imagery use, the authors outline that mental practice may be counterproductive in some patients and result in increased pain. They also discuss the neurophysiological mechanisms underlying the analgesic properties of motor imagery.

- Nadja Schott, Marie-Ottilie Frenkel, Heide Korbus and Karen L. Francis (Université de Stuttgart et d'Heidelberg, Germany; Université de San Francicsco, USA) consider the use of imagery in orthopaedic rehabilitation settings. The authors propose a new structure for clinical interventions based on Gentile's Taxonomy of Tasks (2000) and delivered in a home-based setting. They describe an example of a case-study of a patient with distal radius fracture.

- Estelle Raffin and Karen Reilly (Université Jean Monnet, Saint-Etienne, France; Danish Research Center on Magnetic Resonance, Copenhague, Danemark; Centre de Neurosciences Cognitives et Centre de Recherche des Neurosciences de Lyon, France) develop the concept of phantom limb motor perceptions in amputees. They further question the processes underlying the awareness of a movement as being executed or imagined.

- Audrey Maillet, Valérie Fraix, Stéphane Thobois, Philippe Derost, Bastiaan Bloem, Pierre Pollak and Bettina Debû (Université de Grenoble, Institut des Neurosciences de Grenoble, Centre hospitalier Universitaire de Grenoble, France; Hospices Civils de Lyon et Institut des Sciences Cognitives, France; Hôpital Gabriel Montpied, Clermont-Ferrand, France; Radboud University Nijmegen Medical Center, Nijmegen, The Netherlands; Hôpitaux Universitaires de Genève, Suisse) report experimental data aimed at evaluating motor imagery ability in patients with Parkinson's disease and determine the efficacy of levodopa medication on both actual practice and motor imagery of a locomotor task. Data demonstrate that imagery ability is preserved, even in the advanced stage of the disease, and further support the potential benefits of imagery interventions in a rehabilitation setting.

- Francine Malouin, Arnaud Saimpont, Philip L. Jackson and Carol L. Richards (Université de Laval, Centre interdisciplinaire de recherche en réadaptation et intégration sociale Québec, Canada) review the efficacy of motor imagery practice to optimize the recovery of mobility and locomotor activities in neurorehabilitation They also consider whether imagery ability can be altered by neurological injuries and normal aging.

This special issue is made of twelve contributions written by well-known international imagery researchers, including both experimental data and reviews of literature. They contribute to provide an objective and reliable overview of the current research in imagery and its relationship with actual practice both in the field of motor learning and rehabilitation. Practically, data strongly suggest that imagery is a cost-effective and promising adjunct technique which can be easily implemented within the classical course of motor learning and physical therapy. 


\section{Bibliography}

Craik, K.J.W. (1943). The nature of explanation. Cambridge, Cambridge University Press.

Decety, J., \& Boisson, D. (1990). Effect of brain and spinal cord injuries on motor imagery. European Archives of Psychiatry and Clinical Science, 240, 39-43.

Decety, J. (1993). Should motor imagery be used in physiotherapy? Recent advances in cognitive neurosciences. Physiotherapy Theory and Practice, 9, 193-203.

Feltz, D.L., \& Landers, D.M. (1983). The effects of mental practice on motor skill learning and performance: a metaanalysis. Journal of Sport Psychology, 5, 25-57.
Freud, S. (1950 [1895]). Project for a scientific psychology. Standard Edition, 1, 281-387.

James, W. (1890). Principles of psychology. Chapitre 18: Imagination. Dover Publications.

Jeannerod, M. (1996). About mental physiology: history of the relationships between biology and psychology. Odile Jacob, Paris.

Munk, H. (1881). Uber die Funktionen der Grosshirnrinde (sur les fonctions du cortex cérébral). Hirschwald, Berlin (1890). 